\title{
Co-Existence of Diabetes Mellitus And Pre-Existing Cardiovascular Disease, Diabetes Mellitus, And Pre- Existing Cardiovascular Disease And Mortality in Peritoneal Dialysis Patients
}

\section{Xiaojiang Zhan}

Nanchang University

\section{Yueqiang Wen}

Guangzhou Medical University

\section{Qian Zhou}

Sun Yat-Sen University

Xiaoran Feng

Nanchang University

\section{FenFen Peng}

Southern Medical University

Niansong Wang

Shanghai Jiao Tong University

Xiaoyang Wang

Zhengzhou University

Xianfeng Wu ( $\nabla$ xianfengwu2@163.com )

Shanghai Jiao Tong University https://orcid.org/0000-0001-7447-5189

Original investigation

Keywords: cardiovascular disease, diabetes mellitus, dialysis, mortality

Posted Date: June 17th, 2020

DOI: https://doi.org/10.21203/rs.3.rs-35743/v1

License: (우 (i) This work is licensed under a Creative Commons Attribution 4.0 International License. Read Full License 


\section{Abstract}

Background: Little is known over the effect of co-existence of diabetes mellitus (DM) and pre-existing cardiovascular disease (CVD), DM, and pre-existing CVD on mortality among continuous ambulatory peritoneal dialysis (CAPD) patients.

Methods: A retrospective study, with 2939 incident Chinese CAPD patients from five facilities between January 1, 2005 and December 31, 2018, was conducted. The primary and secondary outcomes were allcause and CVD mortality. The association between these interesting comorbidities and mortality was evaluated using the Cox proportional hazards regression.

Results: Over a median of 35.1 months of follow-up, 519 (17.7\%) patients died, with 258 (8.8\%) CVD mortality. Hypertension was independently associated with co-existence of DM and pre-existing CVD using multinomial logistic regression (odd ratio $13.72,95 \% \mathrm{Cl} 6.14$ to 30.63). After adjusting for confounding factors, DM plus CVD, DM, and pre-existing CVD groups had a higher risk of all-cause mortality (HR 2.85, 95\% $\mathrm{Cl} 2.18$ to 3.72 ; HR $1.89,95 \% \mathrm{Cl} 1.50$ to 2.38 ; and $\mathrm{HR} 1.43,95 \% \mathrm{Cl} 1.07$ to 1.92 ) and CVD mortality (HR $2.79,95 \% \mathrm{Cl} 1.91$ to 4.08 ; $\mathrm{HR} 1.88,95 \% \mathrm{Cl} 1.35$ to 2.61 ; and $\mathrm{HR} 1.82,95 \% \mathrm{Cl} 1.23$ to 2.68 ), respectively, compared to the control group. Compared with those pre-existing CVD patients, DM patients had 1.44 ( $95 \% \mathrm{Cl} 1.04$ to 1.98$)$-time and $1.11(95 \% \mathrm{Cl} 0.72$ to 1.71$)$ risk of all-cause and CVD mortality, respectively. There was no significant interaction between DM and CVD on all-cause and CVD mortality $(\beta=0.203$, $P=0.292 ; \beta=0.281, P=0.123)$ in the study population.

Conclusions: CAPD patients with co-existence of DM and pre-existing CVD at baseline are at highest risk of all-cause and CVD mortality, followed sequentially by DM patients and pre-existing CVD patients, with hypertension as a powerful predictor for co-existence of DM and pre-existing CVD. DM patients have a higher risk of all-cause mortality and similar risk of CVD mortality compared with pre-existing CVD patients.

\section{Introduction}

Although renal replacement treatment has been significantly improved over past decades, the overall prognosis of dialysis patients remains poor, with $40 \%$ of cardiovascular disease (CVD) deaths in this population [1]. Dialysis patients have 10 to 30 times of CVD mortality than the general population [2]. Thus, managing CVD risk is an important part of caring for dialysis patients. Many CVD risk factors (such as diabetes mellitus [DM], hypertension, pre-existing CVD, dyslipidemia, and obesity) have been found to be more common among dialysis individuals than in the general population. DM and pre-existing CVD are independently associated with mortality of the dialysis population [3-6]. A recent meta analysis with 23 studies assessing 86,915 dialysis patients showed that compared with non-DM dialysis, DM dialysis patients have 2.00-time all-cause mortality and 2.11-time CVD mortality, and those with pre-existing CVD have 1.41-time all-cause mortality and 2.53-time CVD mortality compared with those without pre-existing CVD [7]. Furthermore, the co-existence of DM and pre-existing CVD has a poor prognosis in the general and dialysis population $[8,9]$. However, the risk factors for the co-existence of DM and pre-existing CVD, and the association co-existence of DM and pre-existing CVD, DM, and pre-existing CVD and mortality remained 
unknown. In the present study, we aimed to evaluate the effect of co-existence of DM and pre-existing CVD, DM, and pre-existing CVD on mortality at the start of dialysis and mortality among patients on continuous ambulatory peritoneal dialysis (CAPD).

\section{Materials And Methods}

\section{Study Design and Population}

A retrospective cohort study, with 3073 incident CAPD patients from five peritoneal dialysis centers of three provinces in China, between January 1,2005, and December 31, 2018, was conducted. To increase the generalizability of CAPD population, we only excluded those with age $<18$ years or less than 3-month period of follow up. The study was approved by the Human Ethics Committee of each research facility, consistent with the ethical principles of the Declaration of Helsinki.

\section{Data Collection and Definitions}

Data at the start of CAPD were abstracted from medical records by two trained investigators in each facility using uniform and standardized data collection tools. Data included: demographic characteristics (age, sex, body mass index, systolic blood pressure [BP], diastolic BP, 24-hour urine volume, current smoking, and current alcohol consumption); comorbidities (diabetes mellitus [DM], pre-existing CVD, hypertension, hyperlipidemia); medications (calcium channel blockers, beta blockers, angiotensin II receptor blockers/angiotensin-converting enzyme inhibitors [ACEI/ARBs], diuretics, statins, and aspirin); and laboratory parameters (hemoglobin, serum albumin, serum uric acid, estimated glomerular filtration rate [eGFR], cholesterol, triglyceride, high density lipoprotein, low density lipoprotein, high-sensitivity C-reactive protein [hs-CRP]).

The diagnosis of DM was defined as (1) HbA1c $\geq 6.5 \%$, (2) fasting plasma glucose $\geq 126 \mathrm{mg} / \mathrm{dL}$, (3) 2-h plasma glucose $\geq 200 \mathrm{mg} / \mathrm{dL}$ during an OGTT, or (4) in a patient with classic symptoms of hyperglycemia or hyperglycemic crisis, a random plasma glucose $\geq 200 \mathrm{mg} / \mathrm{dL}$. In the absence of unequivocal hyperglycemia, criteria 1 to 3 should be confirmed by repeat testing. [10]. The presence of CVD were defined as coronary heart disease, congestive heart failure, arrhythmias, cerebrovascular disease, or peripheral vascular disease [11]. The diagnosis of hypertension from 2016 Guidelines for the Management of Renal Hypertension in China was defined as systolic blood pressure $>140 \mathrm{mmHg}$ or diastolic blood pressure $>90$ $\mathrm{mmHg}$, or the use of antihypertensive medications [12]. Hyperlipidemia form 2016 Chinese Guideline for the Management of Dyslipidemia in Adults was defined as serum cholesterol levels $\geq 240 \mathrm{mg} / \mathrm{dL}$, triglycerides levels $\geq 200 \mathrm{mg} / \mathrm{dL}$, low density lipoprotein levels $\geq 160 \mathrm{mg} / \mathrm{dL}$, or when the patients were receiving lipidlowering drugs [13]. Current smoking was defined as at least one cigarette a day, and current alcohol consumption defined as $>20$ grams of ethanol a day [14]. eGFR was calculated using the Chronic Kidney Disease Epidemiology Collaboration equation [15].

\section{Outcomes and Follow-Up}


The primary and secondary outcomes were all-cause and CVD mortality, respectively. If the patients died in hospital, the exact death cause was identified by death certificates, and if the patients died outside a hospital, experts would meet a consensus on the death cause, based on the integration of recent health conditions provided by family members, and the medical history and descriptions from each dialysis facility. Patients who died within three months from transferring to hemodialysis to death were considered to be a CAPD failure, and not to be censored.

All patients were followed up until CAPD cessation, death, the end of 8-year duration, or June 30, 2019. Transferring to hemodialysis with survival time $\geq$ three months, renal transplantation, transferring to other centers, loss of follow-up, still survival with a follow-up period of 8 years, or at the end of June 2019 were considered to be censored. All patients were conducted CAPD regimens prescribed by dialysis professionals in accordance with International Standardized Peritoneal Dialysis Guidelines [16], as well as patient's health conditions.

\section{Statistical Analysis}

Variables with missing data before the data analysis were imputed using the missForest method, tackling different types of variables [17]. Incidence was calculated as number of events divided by total valid observational time at risk, scaled to episodes per 1000 years. Data were presented as mean \pm standard deviation or median (interquartile range, IQR) or number (\%). All patients were divided into four groups: control group (patients without DM and pre-existing CVD), CVD group (patients with only pre-existing CVD), DM (patients with only DM) group, and DM plus CVD group (patients with co-existence of DM and preexisting CVD). Baseline variables were compared by the One-Way ANOVA or Kruskal-Wallis tests according to variable distribution (normality tested with Shapiro-Wilk test) for quantitative variables, and the chisquare test when appropriate for categorical variables. Multinomial logistic regression was conducted to estimate adjusted odds ratios for co-existence of HD and pre-existing CVD, DM, and pre-existing CVD groups versus the control group. The following factors were included in multinomial logistic regression, based on findings of previous studies and clinical knowledge $[4,6,7]$ : age, sex, body mass index, systolic $\mathrm{BP}$, diastolic BP, current smoking, current alcohol consumption, 24-hour urine volume, hypertension, hyperlipidemia, hemoglobin, serum albumin, serum uric acid, eGFR, cholesterol, triglyceride, high density lipoprotein, low density lipoprotein, and hs-CRP.

We used Kaplan-Meier curves to investigate the difference of cumulative mortality among four groups over the observational period. To analyze the association between the interesting comorbidities and mortality, we constructed four Cox proportional hazards regression models adjusted for the following factors: Model 1, unadjusted; model 2, model 1 plus age, sex, body mass index, systolic BP, diastolic BP, current smoking, current alcohol consumption, 24-hour urine volume, hypertension, and hyperlipidemia; model 3 , model 2 plus medications; model 4, model 3 plus hemoglobin, serum albumin, serum uric acid, eGFR, cholesterol, triglyceride, high density lipoprotein, low density lipoprotein, and hs-CRP. In addition, the association between comorbidities and mortality were also analyzed among subgroups of men, women, hypertension, non-hypertension, hyperlipidemia, and non-hyperlipidemia. When using patients with pre-existing CVD as a 
reference, we evaluated the risk of mortality in those DM patients. The interaction between DM and preexisting CVD on all-cause and CVD mortality was examined by conducting a formal test of interaction.

\section{Sensitivity Analysis}

First, for all-cause mortality, hemodialysis or renal transplants were considered competing risks. When using hemodialysis or renal transplants as competing risks, we evaluated these interesting comorbidities and all-cause mortality using four the Fine and Gray competing risk models. Similarly, for CVD mortality, non-CVD mortality, hemodialysis or renal transplants were considered competing risks. Second, for patients with a short-term period of follow-up, the interesting outcomes may not be completely observed, underreporting of the incidence of mortality. For fully observing outcomes, we further analyzed the effect of comorbidities at the start of dialysis on mortality in those patients with $\geq 24$-month period of follow-up.

The results of the Cox proportional hazards and the Fine and Gray models were presented as the hazard ratio (HR) and the $95 \%$ confidence interval $(\mathrm{Cl})$. Statistical analyses were conducted by GraphPad Software 8.0 (GraphPad Prism Software Inc., San Diego, California) and the R package 3.6.0 (https://www.rproject.org/). The level of significance was set as 0.05 for all analyses.

\section{Results}

\section{Baseline Characteristics and Comorbidities}

Figure 1 showed the number of participants enrolled and those excluded. The number of potential participants was 3073 , with 42 excluded due to age less than 18 years, and 92 excluded because of less than 3-month dialysis duration. Ultimately, the remaining 2939 patients were eligible for the present analysis.

All variables with less than $5 \%$ missing data were imputed before the data analysis, and there was no missing data for outcomes. Of 2939 with a median age of 50.0 (IQR 39.0-61.0), 1697 (57.7\%) were men, 549 (18.7\%) had DM, 410 (14.0\%) had pre-existing CVD, and 1915 (65.2\%) had hypertension. All patients were divided into four group: DM plus CVD group ( $n=177,6.0 \%)$, DM group ( $n=372,12.7 \%)$, CVD group $(n=233,7.9 \%)$, and the control group $(n=2157,73.4 \%$, Table 1). Compared to the control group, DM plus CVD group tended to be elderly, with higher body mass index, systolic BP, hemoglobin, cholesterol, and triglyceride, but lower diastolic BP, serum uric acid, as well as more likely to be hypertension, hyperlipidemia, taking calcium channel blockers, beta blockers, diuretics, ACEI/ARBs, aspirin, and statins. Additionally, DM patients were likely to be higher percentiles of men and hypertension, higher levels of body mass index and eGFR, and lower levels of diastolic BP and low density lipoprotein, compared with those with pre-existing CVD.

\section{Variables at Baseline and Co-existence of DM and Preexisting CVD, DM, and Preexisting CVD.}

We analyzed the factors associated with co-existence of DM and pre-existing CVD, DM, and pre-existing CVD versus the control group at baseline using the multinomial logistic regression (Table 2). When 
adjusting for confounding factors, we found that elderly age, men, hypertension, hyperlipidemia, and lower levels of serum uric acid were associated with high risk of co-existence of DM and pre-existing CVD, DM, and pre-existing CVD versus the control group. Of note, hypertension was powerfully associated with 13.72 (6.14 to 30.63)-time risk of co-existence of DM and pre-existing CVD versus the control group. In addition, higher levels of body mass index, systolic BP, hemoglobin, and cholesterol, but lower levels of diastolic BP were associated with higher risk of co-existence of DM and pre-existing CVD.

\section{Observational Period and Mortality}

The median observational period was 35.1 (IQR 17.9-61.7) months. During this period, $519(17.7 \%, 95 \% \mathrm{Cl}$ $16.4 \%$ to $19.1 \%$ ) of 2939 patients died, including 258 (43.4\%, 95\% Cl 39.0\% to $47.6 \%)$ CVD deaths, 54 $(10.4 \%, 95 \% \mathrm{Cl} 6.1 \%$ to $15.3 \%)$ infection deaths, $9(1.7 \%, 95 \% \mathrm{Cl} 0.7 \%$ to $2.9 \%)$ gastrointestinal bleeding deaths, $19(3.1 \%, 95 \% \mathrm{Cl} 1.6 \%$ to $4.8 \%)$ tumor deaths, $93(17.9 \%, 95 \% \mathrm{Cl} 14.6 \%$ to $21.3 \%)$ other death causes, and $82(15.8 \%, 95 \% \mathrm{Cl} 12.6 \%$ to $18.9 \%)$ unknown death causes. In addition, $353(12.0 \%, 95 \% \mathrm{Cl} 10.8 \%$ to $13.2 \%)$ transferring to hemodialysis, $153(5.2 \%, 95 \% \mathrm{Cl} 4.4 \%$ to $6.1 \%)$ receiving renal transplants, $26(0.9 \%$, $95 \% \mathrm{Cl} 0.5 \%$ to $1.2 \%)$ transferring to other dialysis centers, and $100(3.4 \%, 95 \% \mathrm{Cl} 2.7 \%$ to $4.1 \%)$ loss of follow-up. The number of all-cause mortality was $89(50.3 \%, 95 \% \mathrm{Cl} 42.6 \%$ to $57.4 \%), 117(31.5 \%, 95 \% \mathrm{Cl}$ $27.2 \%$ to $36.4 \%), 57$ (24.5\%, $95 \% \mathrm{Cl} 19.3 \%$ to $29.8 \%$ ), and 256 (11.9\%, $95 \% \mathrm{Cl} 10.6 \%$ to $13.2 \%)$ in the DM plus CVD, DM, CVD, and control groups, respectively. The number of CVD mortality was $42(23.7 \%, 95 \% \mathrm{Cl}$ $17.5 \%$ to $30.8 \%$ ), 57 (15.3\%, $95 \% \mathrm{Cl} 12.1 \%$ to $19.1 \%), 34$ (14.6\%, $95 \% \mathrm{Cl} 10.1 \%$ to $18.9 \%)$, and 125 (5.8\%, $95 \% \mathrm{Cl} 4.9 \%$ to $6.8 \%)$ in the DM plus CVD, DM, CVD, and control groups, respectively.

The incidence of all-cause mortality was 51.3/1000 patient-years in the study population, with 25.5/1000 patient-years of CVD mortality incidence (Table 3). The incidence of all-cause mortality was $179.4,102.4$, 72.6, and 33.3/1000 patient-years, and CVD mortality incidence was $84.6,49.4,43.3$, and 16.2/1000 patient-years among the DM plus CVD, DM, CVD, and control groups, respectively.

\section{Co-existence of DM and Preexisting CVD, DM, and Preexisting CVD and Mortality}

Survival analysis found that the DM plus CVD group had poorer cumulative survival $(P<0.001)$ and CVD mortality-free survival $(P<0.001)$ compared to the control group (Figure 2$)$. The association between comorbidities and mortality was evaluated by the different Cox proportional hazards regression models (Table 4). When comparing to the control group, the DM plus CVD, DM, and CVD groups had $2.85(95 \% \mathrm{Cl}$ 2.18 to 3.72$), 1.89(95 \% \mathrm{Cl} 1.50$ to 2.38$)$, and 1.43 (95\% $\mathrm{Cl} 1.07$ to 1.92$)$-time risk of all-cause morality, and $2.79(95 \% \mathrm{Cl} 1.91$ to 4.08$), 1.88(95 \% \mathrm{Cl} 1.35$ to 2.61$)$, and 1.82 (95\% 1.23 to 2.68$)$-time risk for CVD mortality compared to the control group in the model 4 , respectively.

Similar trends of the association between comorbidities and mortality were observed among subgroups of men, women, hypertension, non-hypertension, hyperlipidemia, and non-hyperlipidemia (Figure 3). Of note, when comparing to pre-existing CVD patients, DM patients had $1.44(95 \% \mathrm{Cl} 1.04$ to 1.98$)$-time all-cause mortality and $1.11(95 \% \mathrm{Cl} 0.72$ to 1.71$) \mathrm{CVD}$ mortality in the Cox model 4 . In the study population, there was no interaction between DM and pre-existing CVD on all-cause and CVD mortality $(\beta=0.203, P=0.292$; $\beta=0.281, P=0.123$ ). 


\section{Sensitivity Analysis}

When conducting competing risk analyses with hemodialysis or renal transplants as the competing risk factors, the DM plus CVD, DM, and CVD groups had 2.18 (95\% Cl 1.67 to 2.86 ), 1.81 (95\% Cl 1.05 to 3.10 ), and $1.49(95 \% \mathrm{Cl} 1.19$ to 1.86$)$-time risk of all-cause morality compared to the control group, respectively, in the Fine and Gray model 4. Similarly, when using non-CVD mortality, hemodialysis or renal transplants as the competing risk factors, the DM plus CVD, DM, and CVD groups had 2.56 (95\% Cl 1.76 to 3.72 ), 1.81 $(95 \% \mathrm{Cl} 0.82$ to 3.99$)$, and $1.54(95 \% \mathrm{Cl} 1.12$ to 2.10$)$-time risk of all-cause morality, respectively, compared to the control group in the Fine and Gray model 4.

By the end of study, 1022 (34.7\%) adult patients were follow up less than 24 months, with 238 (23.3\%, $95 \% \mathrm{Cl} 20.8 \%$ to $26.2 \%)$ deaths. The remaining 1917 (65.2\%) adult patients were follow up for at least 24 months, with $281(14.7 \%, 95 \% \mathrm{Cl} 13.0 \%$ to $16.1 \%)$ of all-cause mortality and 135 (7.0\%, 95\% Cl 5.9\% to $8.2 \%$ ) of CVD mortality. When comparing to the control group, the DM plus CVD, DM, and CVD groups had 2.17 (95\% $\mathrm{Cl} 1.46$ to 3.23 ), 1.69 (95\% $\mathrm{Cl} 1.23$ to 2.31 ), and 1.44 (95\% $\mathrm{Cl} 1.08$ to 1.92 )-time risk of all-cause mortality, and 2.97 ( $95 \% \mathrm{Cl} 1.70$ to 5.21 ), 2.15 (95\% Cl 1.37 to 3.37 ), and 1.46 (95\% Cl 1.04 to 1.98)-time risk of CVD mortality in the Cox regression model 4, respectively, among adult those with at least 24-month follow-up period.

\section{Discussion}

In our multi-center study of 2939 incident Chinese CAPD patients, the co-existence of DM and pre-existing CVD at the start of dialysis was more strongly associated with all-cause and CVD mortality compared to either DM or pre-existing CVD alone, with DM more associated with all-cause and CVD mortality than preexisting CVD. Similar trends were observed by the competing risk analysis, among subgroups of men, women, hypertension, non-hypertension, hyperlipidemia, and non-hyperlipidemia patients, as well as in those with at least 2-year period of follow up. In addition, hypertension was powerfully independently associated with the co-existence of DM and pre-existing CVD. Of note, DM patients had a higher risk of allcause mortality, but similar risk of CVD mortality than pre-existing CVD patients.

In the non-dialysis population, co-existence of DM and pre-existing CVD is associated with a poorer survival than their counterparts [8]. DM patients with both pre-existing CVD and protein-energy wasting had a 3.3time risk of mortality than DM patients without pre-existing CVD and protein-energy wasting [9]. In the dialysis population, the co-existence of DM and pre-existing CVD is also associated with poor prognosis in dialysis patients $[3,18-20]$. However, the association between co-existence of DM and pre-existing CVD, DM, pre-existing CVD and mortality to date remained unknown. In our study, when comparing to those without DM and pre-existing CVD, patients with co-existence of DM and pre-existing CVD, those with only DM, and those with only pre-existing CVD had 2.85, 1.89, and 1.43-time risk of all-cause mortality, and 2.79, 1.88, and 1.82-time CVD mortality, respectively, indicting that patients with co-existence of DM and pre-existing CVD were at highest risk of all-cause and CVD mortality, followed sequentially by DM patients and pre-existing CVD patients. Similar findings were observed by the competing risk analysis, in the subgroups of men, women, hypertension, non-hypertension, hyperlipidemia, and non-hyperlipidemia patients, as well as those 
with at least 24-month follow-up period. Patients with co-existence of DM and pre-existing CVD at baseline were more likely to be older age, higher percentiles of hypertension and hyperlipidemia, and had higher levels of body mass index compared with other three groups. Previous studies reported that older age, and hypertension are associated with poor prognosis in dialysis [21-23], while being obese may be protective for all-cause mortality in the pre-dialysis and hemodialysis populations, while being underweight suggests increased risk of mortality [24], which is inconsistent with the findings of a meta analysis of non-dialysis population, reporting that relative to normal weight, obesity is associated with significantly higher all-cause mortality, but overweight was associated with significantly lower all-cause mortality [25]. Unmatched baseline variables may affect the reliability of the association between co-existence DM and pre-existing CVD, DM, pre-existing CVD and mortality among CAPD patients.

To date, there is no study pertaining to the predictors for co-existence of DM and pre-existing CVD. In our study, elderly age, men, higher systolic BP, hypertension, hyperlipidemia, and lower serum uric acid were associated with high risk of co-existence of DM and pre-existing CVD, DM, and pre-existing CVD. Lower diastolic BP was associated with higher risk of DM and co-existence of DM and pre-existing CVD, while lower body mass index was associated with higher pre-existing CVD, but higher lower body mass index was associated with DM, and the co-existence of DM and pre-existing CVD. In addition, higher hemoglobin was associated with higher risk of co-existence of DM and pre-existing CVD. It was worth noting that among these predictors above, hypertension was the strongest predictor of co-existence of DM and pre-existing CVD, with 13.72 of odd ratio, followed by hyperlipidemia with 3.51 of odd ratio for co-existence of DM and pre-existing CVD.

In the present study, we found that CAPD patients with only DM had similar risk of CVD mortality (HR 1.11, $95 \% \mathrm{Cl} 0.72$ to 1.71 ) than those with only pre-existing CVD, which was consistent with a previous study of 2432 participants with seven-year incidence rates of fatal and non-fatal myocardial infarction, reporting that among non-dialysis population, DM patients without previous myocardial infarction have similar risk of myocardial infarction (HR $1.20,95 \% \mathrm{Cl} 0.60$ to 2.40 ) compared with those patients with previous myocardial infarction [26]. The difference of interesting outcomes is that we only observed fatal CVD disease including coronary heart disease, congestive heart failure, arrhythmias, cerebrovascular disease, or peripheral vascular disease, but only fatal and non-fatal myocardial infarction was recorded in the abovementioned study. It was worth noting that in our study, we did not identify $82(15.8 \%)$ unknown death causes, which may affect the finding that DM had as high a risk of CVD mortality as pre-existing CVD. Interesting, we found that DM patients had a higher risk of all-cause mortality (HR $1.44,95 \% \mathrm{Cl} 1.04$ to 1.98 ) than those pre-existing CVD patients. DM patients were likely to be higher percentiles of age $\geq 51$ years (76.1\% vs. 64.8\%), higher BMI, eGFR, and low density lipoprotein levels compared with those with preexisting CVD. As all we know, elderly age, higher eGFR at the start of dialysis, and higher low density lipoprotein levels have a adverse effect on the prognosis in dialysis population [21, 27-29]. Unmatched baseline variables may affect the risk of all-cause and CVD mortality between those DM and pre-existing CVD patients.

Strengths of this study included a large sample size from five dialysis facilities, and a detailed assessment and adjustment for all-cause and CVD risk factors. Several limitations should be considered. First, this was 
a retrospective study with potential unaccounted confounding factors and the selection biases. Although after adjusting for confounding variables at baseline, we did not draw conclusions about potential causal relationship between comorbidities and mortality. Nonetheless, fluctuations of HRs were less than $10 \%$ among the model 2,3 , and 4 , suggesting three models were stable and reliable for predicting the interesting outcomes [29]. Second, although experts tried to meet a consensus on the death causes, there remained 82 (15.8\%) unknown death causes, which may under-report the incidence of CVD mortality, and affect the association between the interesting comorbidities and CVD mortality. Thus, in a future study, we need detailed death causes to re-evaluate the risk of CVD mortality between DM and pre-existing CVD. Third, due to focusing on DM as a comorbidity, we did not recorded types of DM and DM-specified factors such as usage of hypoglycemic medications, and duration of DM, which did not affect our findings. Lastly, to enhance the generalizability of CAPD population settings, we only excluded those with age $<18$ years or $<$ 3-month period of follow up. Nonetheless, all eligible patients were from China, suggesting our findings may lack generalization to other ethnic population settings.

\section{Conclusions}

CAPD patients with co-existence of DM and pre-existing CVD at baseline are at highest risk of all-cause and CVD mortality, followed by DM patients and those with pre-existing CVD accordingly, with hypertension as a powerful predictor for co-existence of DM and pre-existing CVD. In addition, DM patients have a higher risk of all-cause, but similar risk of CVD mortality than pre-existing CVD patients. Our findings suggested that a combined assessment of DM and pre-existing CVD compared with separate assessment of the two comorbidities further improved risk stratification of CAPD patients at risk of mortality.

\section{List Of Abbreviations}

CAPD, continuous ambulatory peritoneal dialysis; DM, diabetes mellitus; CVD, cardiovascular disease; BP, blood pressure; ACEI/ARB, beta blockers, angiotensin II receptor blockers/angiotensin-converting enzyme inhibitors; eGFR, estimated glomerular filtration rate; hs-CRP, high-sensitivity C-reactive protein; OR, odds ratio; $\mathrm{HR}$, hazards ratio; $\mathrm{Cl}$, confidence index.

\section{Declarations}

\section{Ethics approval and consent to participate}

The study was consistent with the ethical principles of the Declaration of Helsinki and was approved by the Human Ethics Committee of the Second Affiliated Hospital of Guangzhou Medical University, Zhujiang Hospital of Southern Medical University, Jiujiang No. 1 People's Hospital, Affiliated Sixth People's Hospital, Shanghai Jiao Tong University, The First Affiliated Hospital of Zhengzhou University, and the First Affiliated Hospital of Nanchang University. Written informed consent was obtained from all participants.

\section{Consent for publication}


All authors have approved the submitted version. All authors have agreed both to be personally accountable for the author's own contributions and to ensure that questions related to the accuracy or integrity of any part of the work, even ones in which the author was not personally involved, are appropriately investigated, resolved, and the resolution documented in the literature.

\section{Availability of data and materials}

The datasets used and/or analyzed during the current study are available from the corresponding author on reasonable request.

\section{Competing interests}

The authors declare that they have no competing interests.

\section{Funding}

No.

\section{Acknowledgements}

We express our gratitude to all patients who participated in the study.

\section{Authors' contributions}

XJ Z, contributions to the conception, and drafted the work; XR F, the acquisition of data; FF P, the acquisition of data; $X Y$ W, the acquisition of data; NS W, contributions to the conception and design of the work; $Q, Z$, analysis and interpretation of data; $Y Q$ W, contributions to the conception and design of the work; XF W, contributions to the conception, design of the work, and revised it. All authors have read and approved the manuscript.

\section{References}

1. Hall YN, Chertow GM: End stage renal disease. BMJ Clin Evid 2007, 2007.

2. Jha V, Garcia-Garcia G, Iseki K, Li Z, Naicker S, Plattner B, Saran R, Wang AY, Yang CW: Chronic kidney disease: global dimension and perspectives. Lancet 2013, 382(9888):260-272.

3. Wu X, Yang X, Liu X, Yi C, Guo Q, Feng X, Mao H, Huang F, Yu X: Patient Survival and Technique Failure in Continuous Ambulatory Peritoneal Dialysis Patients with Prior Stroke. Perit Dial Int 2016, 36(3):308314.

4. Ishii J, Takahashi H, Kitagawa F, Kuno A, Okuyama R, Kawai H, Muramatsu T, Naruse H, Motoyama S, Matsui $S$ et al: Multimarker approach to risk stratification for long-term mortality in patients on chronic hemodialysis. Circ J 2015, 79(3):656-663.

5. Narumi T, Watanabe T, Kadowaki S, Kinoshita D, Yokoyama M, Honda Y, Otaki Y, Nishiyama S, Takahashi $\mathrm{H}$, Arimoto $\mathrm{T}$ et al: Impact of serum omentin-1 levels on cardiac prognosis in patients with heart failure. Cardiovasc Diabetol 2014, 13:84. 
6. Kim CH, Kim SJ, Lee MJ, Kwon YE, Kim YL, Park KS, Ryu HJ, Oh HJ, Han SH, Yoo TH et al: LDL cholesterol affects clinical outcomes in incident hemodialysis patients during the early stages of dialysis. Blood Purif 2014, 38(2):131-139.

7. Ma L, Zhao S: Risk factors for mortality in patients undergoing hemodialysis: A systematic review and meta-analysis. Int J Cardiol 2017, 238:151-158.

8. Bueno H: [Prevention and treatment of ischemic heart disease in patients with diabetes mellitus]. Rev Esp Cardiol 2002, 55(9):975-986.

9. Chung SH, Han DC, Noh H, Jeon JS, Kwon SH, Lindholm B, Lee HB: Risk factors for mortality in diabetic peritoneal dialysis patients. Nephrol Dial Transplant 2010, 25(11):3742-3748.

10. American Diabetes A: Diagnosis and classification of diabetes mellitus. Diabetes Care 2011, 34 Suppl 1:S62-69.

11. Wen Y, Zhan X, Wang N, Peng F, Feng X, Wu X: Monocyte/Lymphocyte Ratio and Cardiovascular Disease Mortality in Peritoneal Dialysis Patients. Mediators Inflamm 2020, 2020:9852507.

12. Branch CMDAN: 2016 Guidelines for the management of renal hypertension in China. Chinese Medical Journal 2017, 97:9.

13. Joint committee issued Chinese guideline for the management of dyslipidemia in a: [2016 Chinese guideline for the management of dyslipidemia in adults]. Zhonghua Xin Xue Guan Bing Za Zhi 2016, 44(10):833-853.

14. Tu W, Wu J, Jian G, Lori J, Tang Y, Cheng H, Wu X, Wang N: Asymptomatic hyperuricemia and incident stroke in elderly Chinese patients without comorbidities. Eur J Clin Nutr 2019, 73(10):1392-1402.

15. Zhang L, Wang F, Wang L, Wang W, Liu B, Liu J, Chen M, He Q, Liao Y, Yu X et al: Prevalence of chronic kidney disease in China: a cross-sectional survey. Lancet 2012, 379(9818):815-822.

16. Woodrow G, Fan SL, Reid C, Denning J, Pyrah AN: Renal Association Clinical Practice Guideline on peritoneal dialysis in adults and children. BMC Nephrol 2017, 18(1):333.

17. Stekhoven DJ, Buhlmann P: MissForest-non-parametric missing value imputation for mixed-type data. Bioinformatics 2012, 28(1):112-118.

18. Tien KJ, Lin ZZ, Chio CC, Wang JJ, Chu CC, Sun YM, Kan WC, Chien CC: Epidemiology and mortality of new-onset diabetes after dialysis: Taiwan national cohort study. Diabetes Care 2013, 36(10):30273032.

19. Yang X, Yi C, Liu X, Guo Q, Yang R, Cao P, Lin J, Mao H, Yu X: Clinical outcome and risk factors for mortality in Chinese patients with diabetes on peritoneal dialysis: a 5-year clinical cohort study. Diabetes Res Clin Pract 2013, 100(3):354-361.

20. Ganesh SK, Hulbert-Shearon T, Port FK, Eagle K, Stack AG: Mortality differences by dialysis modality among incident ESRD patients with and without coronary artery disease. J Am Soc Nephrol 2003, $14(2): 415-424$.

21. Han SS, Park JY, Kang S, Kim KH, Ryu DR, Kim H, Joo KW, Lim CS, Kim YS, Kim DK: Dialysis Modality and Mortality in the Elderly: A Meta-Analysis. Clin J Am Soc Nephrol 2015, 10(6):983-993. 
22. Vaios V, Georgianos PI, Liakopoulos V, Agarwal R: Assessment and Management of Hypertension among Patients on Peritoneal Dialysis. Clin J Am Soc Nephrol 2019, 14(2):297-305.

23. Prichard SS: Management of hyperlipidemia in patients on peritoneal dialysis: current approaches. Kidney Int Supp/ 2006(103):S115-117.

24. Ladhani M, Craig JC, Irving M, Clayton PA, Wong G: Obesity and the risk of cardiovascular and allcause mortality in chronic kidney disease: a systematic review and meta-analysis. Nephrol Dial Transplant 2017, 32(3):439-449.

25. Flegal KM, Kit BK, Orpana H, Graubard BI: Association of all-cause mortality with overweight and obesity using standard body mass index categories: a systematic review and meta-analysis. JAMA 2013, 309(1):71-82.

26. Haffner SM, Lehto S, Ronnemaa T, Pyorala K, Laakso M: Mortality from coronary heart disease in subjects with type 2 diabetes and in nondiabetic subjects with and without prior myocardial infarction. N Engl J Med 1998, 339(4):229-234.

27. Wright S, Klausner D, Baird B, Williams ME, Steinman T, Tang H, Ragasa R, Goldfarb-Rumyantzev AS: Timing of dialysis initiation and survival in ESRD. Clin J Am Soc Nephrol 2010, 5(10):1828-1835.

28. Okuda Y, Soohoo M, Tang Y, Obi Y, Laster M, Rhee CM, Streja E, Kalantar-Zadeh K: Estimated GFR at Dialysis Initiation and Mortality in Children and Adolescents. Am J Kidney Dis 2019, 73(6):797-805.

29. Krane V, Winkler K, Drechsler C, Lilienthal J, Marz W, Wanner C, German D, Dialysis Study I: Association of LDL cholesterol and inflammation with cardiovascular events and mortality in hemodialysis patients with type 2 diabetes mellitus. Am J Kidney Dis 2009, 54(5):902-911.

\section{Tables}


Table 1. Baseline demographic characteristics, medications, and laboratory parameters among four groups

\begin{tabular}{|c|c|c|c|c|c|c|}
\hline Groups & $\begin{array}{l}\text { Study } \\
\text { population }\end{array}$ & $\begin{array}{l}\text { Control } \\
\text { group }\end{array}$ & CVD group & DM group & $\begin{array}{l}\text { DM plus } \\
\text { CVD group }\end{array}$ & $\begin{array}{l}\mathrm{P}- \\
\text { value }\end{array}$ \\
\hline $\mathrm{N}$ & 2939 & 2157 & 233 & 372 & 177 & \\
\hline Age, years & $\begin{array}{l}50.0(39.0- \\
61.0)\end{array}$ & $\begin{array}{l}46.0(36.0- \\
56.0)\end{array}$ & $\begin{array}{l}58.0(45.0- \\
69.0)\end{array}$ & $\begin{array}{l}59.0(51.0- \\
66.0)\end{array}$ & $\begin{array}{l}63.0(57.0- \\
69.0)\end{array}$ & $<0.001$ \\
\hline Men, \% & $\begin{array}{l}1697 \\
(57.7 \%)\end{array}$ & $\begin{array}{l}1230 \\
(57.0 \%)\end{array}$ & $\begin{array}{l}137 \\
(58.8 \%)\end{array}$ & $\begin{array}{l}227 \\
(61.0 \%)\end{array}$ & $103(58.2 \%)$ & 0.529 \\
\hline $\begin{array}{l}\text { Body mass index, } \\
\mathrm{kg} / \mathrm{m}^{2}\end{array}$ & $22.4 \pm 3.6$ & $22.1 \pm 3.5$ & $21.9 \pm 4.0$ & $23.2 \pm 3.7$ & $24.5 \pm 3.3$ & $<0.001$ \\
\hline $\begin{array}{l}\text { Systolic BP, } \\
\mathrm{mmHg}\end{array}$ & $150.0 \pm 25.6$ & $148.8 \pm 25.6$ & $151.6 \pm 25.9$ & $153.2 \pm 24.5$ & $156.6 \pm 25.80$ & $<0.001$ \\
\hline $\begin{array}{l}\text { Diastolic BP, } \\
\mathrm{mmHg}\end{array}$ & $87.5 \pm 15.7$ & $88.8 \pm 16.0$ & $87.3 \pm 15.7$ & $83.1 \pm 13.3$ & $80.8 \pm 13.9$ & $<0.001$ \\
\hline $\begin{array}{l}24- \\
\text { hour urine volume, } \\
\mathrm{ml}\end{array}$ & $\begin{array}{l}800(500- \\
1200)\end{array}$ & $\begin{array}{l}800(500- \\
1200)\end{array}$ & $\begin{array}{l}800(400- \\
1300)\end{array}$ & $\begin{array}{l}800(500- \\
1200)\end{array}$ & $\begin{array}{l}800(500- \\
1150)\end{array}$ & 0.704 \\
\hline $\begin{array}{l}\text { Current smoking, } \\
(\%)\end{array}$ & $\begin{array}{l}294 \\
(10.00 \%)\end{array}$ & $\begin{array}{l}211 \\
(9.78 \%)\end{array}$ & $\begin{array}{l}26 \\
(11.16 \%)\end{array}$ & $36(9.68 \%)$ & $21(11.86 \%)$ & 0.756 \\
\hline $\begin{array}{l}\text { Current alcohol } \\
\text { consumption, (\%) }\end{array}$ & $108(3.7 \%)$ & $84(3.9 \%)$ & $8(3.4 \%)$ & $11(3.0 \%)$ & $5(2.8 \%)$ & 0.745 \\
\hline Hypertension, (\%) & $\begin{array}{l}1915 \\
(65.2 \%)\end{array}$ & $\begin{array}{l}1253 \\
(58.1 \%)\end{array}$ & $\begin{array}{l}183 \\
(78.5 \%)\end{array}$ & $\begin{array}{l}308 \\
(82.8 \%)\end{array}$ & 171 (96.6\%) & $<0.001$ \\
\hline $\begin{array}{l}\text { Hyperlipidemia, } \\
(\%)\end{array}$ & $\begin{array}{l}533 \\
(18.1 \%)\end{array}$ & $\begin{array}{l}291 \\
(13.5 \%)\end{array}$ & $64(27.5 \%)$ & $\begin{array}{l}106 \\
(28.5 \%)\end{array}$ & $72(40.7 \%)$ & $<0.001$ \\
\hline $\begin{array}{l}\text { Calcium channel } \\
\text { blockers, (\%) }\end{array}$ & $\begin{array}{l}2201 \\
(74.9 \%)\end{array}$ & $\begin{array}{l}1567 \\
(72.7 \%)\end{array}$ & $\begin{array}{l}178 \\
(76.4 \%)\end{array}$ & $\begin{array}{l}294 \\
(79.0 \%)\end{array}$ & $162(91.5 \%)$ & $<0.001$ \\
\hline Beta blockers, (\%) & $\begin{array}{l}1213 \\
(41.3 \%)\end{array}$ & $\begin{array}{l}877 \\
(40.7 \%)\end{array}$ & $\begin{array}{l}100 \\
(42.9 \%)\end{array}$ & $\begin{array}{l}145 \\
(39.0 \%)\end{array}$ & $91(51.4 \%)$ & 0.003 \\
\hline Diuretics, (\%) & $200(6.8 \%)$ & $104(4.8 \%)$ & $15(6.4 \%)$ & 47 (12.6\%) & 34 (19.2\%) & $<0.001$ \\
\hline ACEI/ARBs, (\%) & $\begin{array}{l}1012 \\
(34.4 \%)\end{array}$ & $\begin{array}{l}671 \\
(31.1 \%)\end{array}$ & 89 (38.2\%) & $\begin{array}{l}155 \\
(41.7 \%)\end{array}$ & $97(54.8 \%)$ & $<0.001$ \\
\hline Aspirin, (\%) & $244(8.3 \%)$ & $102(4.7 \%)$ & $26(11.2 \%)$ & $54(14.5 \%)$ & $62(35.0 \%)$ & $<0.001$ \\
\hline Statins, (\%) & $\begin{array}{l}416 \\
(14.2 \%)\end{array}$ & $\begin{array}{l}218 \\
(10.1 \%)\end{array}$ & $55(23.6 \%)$ & $80(21.5 \%)$ & $63(35.6 \%)$ & $<0.001$ \\
\hline Hemoglobin, g/dL & $9.25 \pm 2.83$ & $9.11 \pm 2.82$ & $9.47 \pm 2.80$ & $9.46 \pm 2.83$ & $10.16 \pm 2.76$ & $<0.001$ \\
\hline $\begin{array}{l}\text { Serum albumin, } \\
\mathrm{g} / \mathrm{dL}\end{array}$ & $3.47 \pm 0.56$ & $3.47 \pm 0.56$ & $3.47 \pm 0.59$ & $3.45 \pm 0.56$ & $3.48 \pm 0.61$ & 0.939 \\
\hline Serum uric acid, & $6.92 \pm 2.34$ & $6.99 \pm 2.37$ & $6.73 \pm 2.10$ & $6.70 \pm 2.31$ & $6.71 \pm 2.32$ & 0.049 \\
\hline
\end{tabular}




\begin{tabular}{|c|c|c|c|c|c|c|}
\hline $\begin{array}{l}\text { eGFR, } \\
\mathrm{mL} / \mathrm{min} / 1.73 \mathrm{~m}^{2}\end{array}$ & $\begin{array}{l}6.44(4.74- \\
8.34)\end{array}$ & $\begin{array}{l}6.40(4.72- \\
8.28)\end{array}$ & $\begin{array}{l}5.91(4.43- \\
7.98)\end{array}$ & $\begin{array}{l}6.71(4.85- \\
8.60)\end{array}$ & $\begin{array}{l}6.63(4.98- \\
8.75)\end{array}$ & 0.683 \\
\hline $\begin{array}{l}\text { Cholesterol, } \\
\mathrm{mg} / \mathrm{dL}\end{array}$ & $\begin{array}{l}151.6 \\
(117.9- \\
183.0)\end{array}$ & $\begin{array}{l}148.9 \\
(116.1- \\
181.8)\end{array}$ & $\begin{array}{l}157.4 \\
(125.3- \\
185.6)\end{array}$ & $\begin{array}{l}153.2 \\
(119.9- \\
184.5)\end{array}$ & $\begin{array}{l}157.2 \\
(129.5- \\
187.9)\end{array}$ & 0.031 \\
\hline $\begin{array}{l}\text { Triglyceride, } \\
\mathrm{mg} / \mathrm{dL}\end{array}$ & $\begin{array}{l}93.92 \\
(55.82- \\
153.28)\end{array}$ & $\begin{array}{l}93.6(55.8- \\
151.6)\end{array}$ & $\begin{array}{l}92.4(47.8- \\
158.6)\end{array}$ & $\begin{array}{l}93.3(56.9- \\
155.5)\end{array}$ & $\begin{array}{l}114.3(64.0- \\
158.6)\end{array}$ & 0.030 \\
\hline $\begin{array}{l}\text { High density } \\
\text { lipoprotein, mg/dL }\end{array}$ & $\begin{array}{l}39.57 \\
(31.32- \\
49.50)\end{array}$ & $\begin{array}{l}39.4(31.5- \\
49.5)\end{array}$ & $\begin{array}{l}41.4(31.8- \\
48.7)\end{array}$ & $\begin{array}{l}40.5(30.8- \\
51.8)\end{array}$ & $\begin{array}{l}37.1(29.8- \\
47.9)\end{array}$ & 0.291 \\
\hline $\begin{array}{l}\text { Low density } \\
\text { lipoprotein, mg/dL }\end{array}$ & $\begin{array}{l}81.6(48.0- \\
116.8)\end{array}$ & $\begin{array}{l}81.3(49.9- \\
116.1)\end{array}$ & $\begin{array}{l}79.3(25.4- \\
116.1)\end{array}$ & $\begin{array}{l}85.7(49.0- \\
121.6)\end{array}$ & $\begin{array}{l}79.3(29.5- \\
122.2)\end{array}$ & 0.444 \\
\hline hs-CRP, mg/L & $\begin{array}{l}4.37(1.91- \\
14.18)\end{array}$ & $\begin{array}{l}4.24(1.90- \\
13.10)\end{array}$ & $\begin{array}{l}4.74(1.93- \\
18.70)\end{array}$ & $\begin{array}{l}5.00(2.14- \\
18.75)\end{array}$ & $\begin{array}{l}4.74(1.70- \\
18.91)\end{array}$ & 0.181 \\
\hline
\end{tabular}

DM, diabetes mellitus; CVD, cardiovascular disease; BP, blood pressure; ACEI/ARB, beta blockers, angiotensin II receptor blockers/angiotensin-converting enzyme inhibitors; eGFR, estimated glomerular filtration rate; hs-CRP, high-sensitivity C-reactive protein. 
Table 2. Adjusted ORs for co-existence of HD and pre-existing CVD, DM, and pre-existing CVD groups using the multinomial logistic regression.

\begin{tabular}{|c|c|c|c|c|c|c|c|}
\hline \multirow[t]{2}{*}{ Control group } & \multicolumn{2}{|c|}{$\begin{array}{l}\text { Pre-existing } \\
\text { CVD group }\end{array}$} & \multicolumn{2}{|c|}{ DM group } & \multicolumn{2}{|c|}{$\begin{array}{l}\text { DM plus pre-existing } \\
\text { CVD group }\end{array}$} & \multirow[b]{2}{*}{$95 \% \mathrm{Cl}$} \\
\hline & & OR & $95 \% \mathrm{Cl}$ & OR & $95 \% \mathrm{Cl}$ & OR & \\
\hline Age, per increase 10 year & 1.0 (ref.) & 1.53 & $\begin{array}{l}1.42 \text { to } \\
1.64\end{array}$ & 1.52 & 1.43 to 1.62 & 1.85 & $\begin{array}{l}1.70 \text { to } \\
2.10\end{array}$ \\
\hline $\begin{array}{l}\text { Women, men as a } \\
\text { reference }\end{array}$ & 1.0 (ref.) & 0.79 & $\begin{array}{l}0.58 \text { to } \\
1.06\end{array}$ & 0.74 & 0.57 to 0.95 & 0.78 & $\begin{array}{l}0.53 \text { to } \\
1.13\end{array}$ \\
\hline BMI, per increase $1 \mathrm{~kg} / \mathrm{m}^{2}$ & 1.0 (ref.) & 0.96 & $\begin{array}{l}0.92 \text { to } \\
0.99\end{array}$ & 1.06 & 1.03 to 1.10 & 1.18 & $\begin{array}{l}1.13 \text { to } \\
1.23\end{array}$ \\
\hline $\begin{array}{l}\text { Systolic BP, per increase } 10 \\
\mathrm{mmHg}\end{array}$ & 1.0 (ref.) & 1.02 & $\begin{array}{l}0.95 \text { to } \\
1.09\end{array}$ & 1.12 & 1.06 to 1.18 & 1.21 & $\begin{array}{l}1.12 \text { to } \\
1.31\end{array}$ \\
\hline $\begin{array}{l}\text { Diastolic BP, per increase } \\
10 \mathrm{mmHg}\end{array}$ & 1.0 (ref.) & 1.01 & $\begin{array}{l}0.91 \text { to } \\
1.12\end{array}$ & 0.76 & 0.69 to 0.83 & 0.66 & $\begin{array}{l}0.57 \text { to } \\
0.75\end{array}$ \\
\hline Hypertension, yes/no & 1.0 (ref.) & 2.26 & $\begin{array}{l}1.60 \text { to } \\
3.17\end{array}$ & 2.84 & 2.10 to 3.84 & 13.72 & $\begin{array}{l}6.14 \text { to } \\
30.63\end{array}$ \\
\hline Hyperlipidemia, yes/no & 1.0 (ref.) & 2.20 & $\begin{array}{l}1.58 \text { to } \\
3.06\end{array}$ & 2.31 & 1.75 to 3.07 & 3.51 & $\begin{array}{l}2.41 \text { to } \\
5.12\end{array}$ \\
\hline $\begin{array}{l}\text { Hemoglobin, per increase } 1 \\
\mathrm{mg} / \mathrm{dL}\end{array}$ & 1.0 (ref.) & 1.02 & $\begin{array}{l}0.97 \text { to } \\
1.07\end{array}$ & 1.02 & 0.98 to 1.06 & 1.09 & $\begin{array}{l}1.03 \text { to } \\
1.16\end{array}$ \\
\hline $\begin{array}{l}\text { Serum uric acid, per } \\
\text { increase } 1 \mathrm{mg} / \mathrm{dL}\end{array}$ & 1.0 (ref.) & 0.95 & $\begin{array}{l}0.90 \text { to } \\
1.01\end{array}$ & 0.94 & 0.89 to 0.99 & 0.92 & $\begin{array}{l}0.86 \text { to } \\
1.00\end{array}$ \\
\hline
\end{tabular}

The following variables at baseline were in the multinomial logistic regression model: age, sex, body mass index, systolic BP, diastolic BP, current smoking, current alcohol consumption, 24-hour urine volume, hypertension, hyperlipidemia, hemoglobin, serum albumin, serum uric acid, eGFR, cholesterol, triglyceride, high density lipoprotein, low density lipoprotein, and hs-CRP.

DM, diabetes mellitus; CVD, cardiovascular disease; BP, blood pressure; eGFR, estimated glomerular filtration rate; hs-CRP, high-sensitivity C-reactive protein; OR, odds ratio; $\mathrm{Cl}$, confidence interval. 
Table 3. All-cause and CVD mortality incidence.

\begin{tabular}{|c|c|c|c|c|c|c|c|}
\hline $\begin{array}{l}\text { All-cause } \\
\text { mortality }\end{array}$ & $\begin{array}{l}\text { CVD } \\
\text { mortality }\end{array}$ & $\begin{array}{l}\text { Time } \\
\text { at risk } \\
\text { (years) }\end{array}$ & $\begin{array}{l}\text { All-cause mortality } \\
\text { incidence (/1000 } \\
\text { patient-years) }\end{array}$ & $\begin{array}{l}95 \% \\
\mathrm{Cl}\end{array}$ & $\begin{array}{l}\text { CVD mortality } \\
\text { incidence } \\
\text { (/1000 patient- } \\
\text { years) }\end{array}$ & $\begin{array}{l}95 \% \\
\mathrm{Cl}\end{array}$ & \\
\hline $\begin{array}{l}\text { Study } \\
\text { population }\end{array}$ & 519 & 258 & 10122.2 & 51.3 & 47.0 to 55.7 & 25.5 & $\begin{array}{l}22.6 \\
\text { to } \\
28.7\end{array}$ \\
\hline $\begin{array}{l}\text { Control } \\
\text { group }\end{array}$ & 256 & 125 & 7697.3 & 33.3 & 29.1 to 37.6 & 16.2 & $\begin{array}{l}13.5 \\
\text { to } \\
19.3\end{array}$ \\
\hline CVD group & 57 & 34 & 785.6 & 72.6 & 55.2 to 90.2 & 43.3 & $\begin{array}{l}31.7 \\
\text { to } \\
57.8\end{array}$ \\
\hline DM group & 117 & 57 & 1143.1 & 102.4 & 86.2 to 117.5 & 49.9 & $\begin{array}{l}37.4 \\
\text { to } \\
61.5\end{array}$ \\
\hline $\begin{array}{l}\text { DM plus } \\
\text { CVD group }\end{array}$ & 89 & 42 & 496.2 & 179.4 & 155.5 to 206.2 & 84.6 & $\begin{array}{l}62.4 \\
\text { to } \\
108.8\end{array}$ \\
\hline
\end{tabular}

Incidence was calculated as number of events divided by total valid observational time at risk, scaled to episodes per 1000 years.

Control group: patients without DM and pre-existing CVD.

DM, diabetes mellitus; CVD, cardiovascular disease; Cl, confidence interval. 
Table 4. Adjusted HRs for mortality among different Cox proportional hazards regression models.

\begin{tabular}{|c|c|c|c|c|c|c|c|c|}
\hline & \multicolumn{2}{|c|}{ Model 1} & \multicolumn{2}{|c|}{ Model 2} & \multicolumn{2}{|c|}{ Model 3} & \multicolumn{2}{|c|}{ Model 4} \\
\hline & $\mathrm{HR}$ & $95 \% \mathrm{Cl}$ & $\mathrm{HR}$ & $95 \% \mathrm{Cl}$ & $\mathrm{HR}$ & $95 \% \mathrm{Cl}$ & $\mathrm{HR}$ & $95 \% \mathrm{Cl}$ \\
\hline \multicolumn{9}{|l|}{$\begin{array}{l}\text { All-cause } \\
\text { mortality }\end{array}$} \\
\hline Control group & \multicolumn{8}{|c|}{ Reference } \\
\hline CVD group & 2.22 & $\begin{array}{l}1.66 \text { to } \\
2.95\end{array}$ & 1.41 & $\begin{array}{l}1.05 \text { to } \\
1.89\end{array}$ & 1.41 & $\begin{array}{l}1.05 \text { to } \\
1.89\end{array}$ & 1.43 & $\begin{array}{l}1.07 \text { to } \\
1.92\end{array}$ \\
\hline DM group & 3.13 & $\begin{array}{l}2.51 \text { to } \\
3.89\end{array}$ & 1.87 & $\begin{array}{l}1.48 \text { to } \\
2.35\end{array}$ & 1.87 & $\begin{array}{l}1.48 \text { to } \\
2.35\end{array}$ & 1.89 & $\begin{array}{l}1.50 \text { to } \\
2.38\end{array}$ \\
\hline $\begin{array}{l}\text { DM plus CVD } \\
\text { group }\end{array}$ & 5.56 & $\begin{array}{l}4.36 \text { to } \\
7.08\end{array}$ & 2.78 & $\begin{array}{l}2.13 \text { to } \\
3.63\end{array}$ & 2.78 & $\begin{array}{l}2.13 \text { to } \\
3.63\end{array}$ & 2.85 & $\begin{array}{l}2.18 \text { to } \\
3.72\end{array}$ \\
\hline \multicolumn{9}{|l|}{ CVD mortality } \\
\hline Control group & \multicolumn{8}{|c|}{ Reference } \\
\hline CVD group & 2.70 & $\begin{array}{l}1.85 \text { to } \\
3.94\end{array}$ & 1.82 & $\begin{array}{l}1.23 \text { to } \\
2.69\end{array}$ & 1.82 & $\begin{array}{l}1.23 \text { to } \\
2.69\end{array}$ & 1.82 & $\begin{array}{l}1.23 \text { to } \\
2.68\end{array}$ \\
\hline DM group & 3.13 & $\begin{array}{l}2.29 \text { to } \\
4.28\end{array}$ & 1.93 & $\begin{array}{l}1.39 \text { to } \\
2.69\end{array}$ & 1.93 & $\begin{array}{l}1.39 \text { to } \\
2.69\end{array}$ & 1.88 & $\begin{array}{l}1.35 \text { to } \\
2.61\end{array}$ \\
\hline $\begin{array}{l}\text { DM plus CVD } \\
\text { group }\end{array}$ & 5.39 & $\begin{array}{l}3.80 \text { to } \\
7.66\end{array}$ & 2.87 & $\begin{array}{l}1.95 \text { to } \\
4.22\end{array}$ & 2.87 & $\begin{array}{l}1.95 \text { to } \\
4.22\end{array}$ & 2.79 & $\begin{array}{l}1.91 \text { to } \\
4.08\end{array}$ \\
\hline
\end{tabular}

Model 1, unadjusted; model 2, model 1 plus age, sex, body mass index, systolic BP, diastolic BP, current smoking, current alcohol consumption, 24-hour urine volume, hypertension, and hyperlipidemia; model 3 , model 2 plus medications; model 4, model 3 plus hemoglobin, serum albumin, serum uric acid, eGFR, cholesterol, triglyceride, high density lipoprotein, low density lipoprotein, and hs-CRP.

Control group: participants without DM and pre-existing CVD.

DM, diabetes mellitus; CVD, cardiovascular disease; BP, blood pressure; eGFR, estimated glomerular filtration rate; hs-CRP, high-sensitivity C-reactive protein; $\mathrm{HR}$, hazard ratio; $\mathrm{Cl}$, confidence interval. 
Table 5. Adjusted HRs for mortality among the Fine and Gray competing risk models.

\begin{tabular}{|c|c|c|c|c|c|c|c|c|}
\hline & \multicolumn{2}{|c|}{ Model 1} & \multicolumn{2}{|c|}{ Model 2} & \multicolumn{2}{|c|}{ Model 3} & \multicolumn{2}{|c|}{ Model 4} \\
\hline & $\mathrm{HR}$ & $95 \% \mathrm{Cl}$ & HR & $95 \% \mathrm{Cl}$ & $\mathrm{HR}$ & $95 \% \mathrm{Cl}$ & $H R$ & $95 \% \mathrm{Cl}$ \\
\hline \multicolumn{9}{|l|}{$\begin{array}{l}\text { All-cause } \\
\text { mortality }\end{array}$} \\
\hline Control group & \multicolumn{8}{|c|}{ Reference } \\
\hline CVD group & 2.52 & $\begin{array}{l}1.87 \text { to } \\
3.39\end{array}$ & 1.46 & $\begin{array}{l}1.17 \text { to } \\
1.81\end{array}$ & 1.49 & $\begin{array}{l}1.20 \text { to } \\
1.86\end{array}$ & 1.49 & $\begin{array}{l}1.19 \text { to } \\
1.86\end{array}$ \\
\hline DM group & 3.37 & $\begin{array}{l}2.66 \text { to } \\
4.26\end{array}$ & 1.73 & $\begin{array}{l}1.01 \text { to } \\
2.97\end{array}$ & 1.77 & $\begin{array}{l}1.03 \text { to } \\
3.03\end{array}$ & 1.81 & $\begin{array}{l}1.05 \text { to } \\
3.10\end{array}$ \\
\hline $\begin{array}{l}\text { DM plus CVD } \\
\text { group }\end{array}$ & 6.65 & $\begin{array}{l}5.08 \text { to } \\
8.71\end{array}$ & 2.09 & $\begin{array}{l}1.60 \text { to } \\
2.73\end{array}$ & 2.15 & $\begin{array}{l}1.65 \text { to } \\
2.82\end{array}$ & 2.18 & $\begin{array}{l}1.67 \text { to } \\
2.86\end{array}$ \\
\hline \multicolumn{9}{|l|}{ CVD mortality } \\
\hline Control group & \multicolumn{8}{|c|}{ Reference } \\
\hline CVD group & 1.89 & $\begin{array}{l}1.22 \text { to } \\
2.93\end{array}$ & 1.58 & $\begin{array}{l}1.15 \text { to } \\
2.16\end{array}$ & 1.58 & $\begin{array}{l}1.15 \text { to } \\
2.16\end{array}$ & 1.54 & $\begin{array}{l}1.12 \text { to } \\
2.10\end{array}$ \\
\hline DM group & 3.16 & $\begin{array}{l}2.28 \text { to } \\
4.38\end{array}$ & 1.93 & $\begin{array}{l}0.88 \text { to } \\
4.25\end{array}$ & 1.93 & $\begin{array}{l}0.88 \text { to } \\
4.25\end{array}$ & 1.81 & $\begin{array}{l}0.82 \text { to } \\
3.99\end{array}$ \\
\hline $\begin{array}{l}\text { DM plus CVD } \\
\text { group }\end{array}$ & 5.69 & $\begin{array}{l}4.02 \text { to } \\
8.07\end{array}$ & 2.56 & $\begin{array}{l}1.76 \text { to } \\
3.72\end{array}$ & 2.56 & $\begin{array}{l}1.76 \text { to } \\
3.72\end{array}$ & 2.56 & $\begin{array}{l}1.76 \text { to } \\
3.72\end{array}$ \\
\hline
\end{tabular}

Model 1, unadjusted; model 2, model 1 plus age, sex, body mass index, systolic BP, diastolic BP, current smoking, current alcohol consumption, 24-hour urine volume, hypertension, and hyperlipidemia; model 3 , model 2 plus medications; model 4, model 3 plus hemoglobin, serum albumin, serum uric acid, eGFR, cholesterol, triglyceride, high density lipoprotein, low density lipoprotein, and hs-CRP.

Control group: participants without DM and pre-existing CVD.

DM, diabetes mellitus; CVD, cardiovascular disease; BP, blood pressure; eGFR, estimated glomerular filtration rate; hs-CRP, high-sensitivity C-reactive protein; $\mathrm{HR}$, hazard ratio; $\mathrm{Cl}$, confidence interval.

\section{Figures}




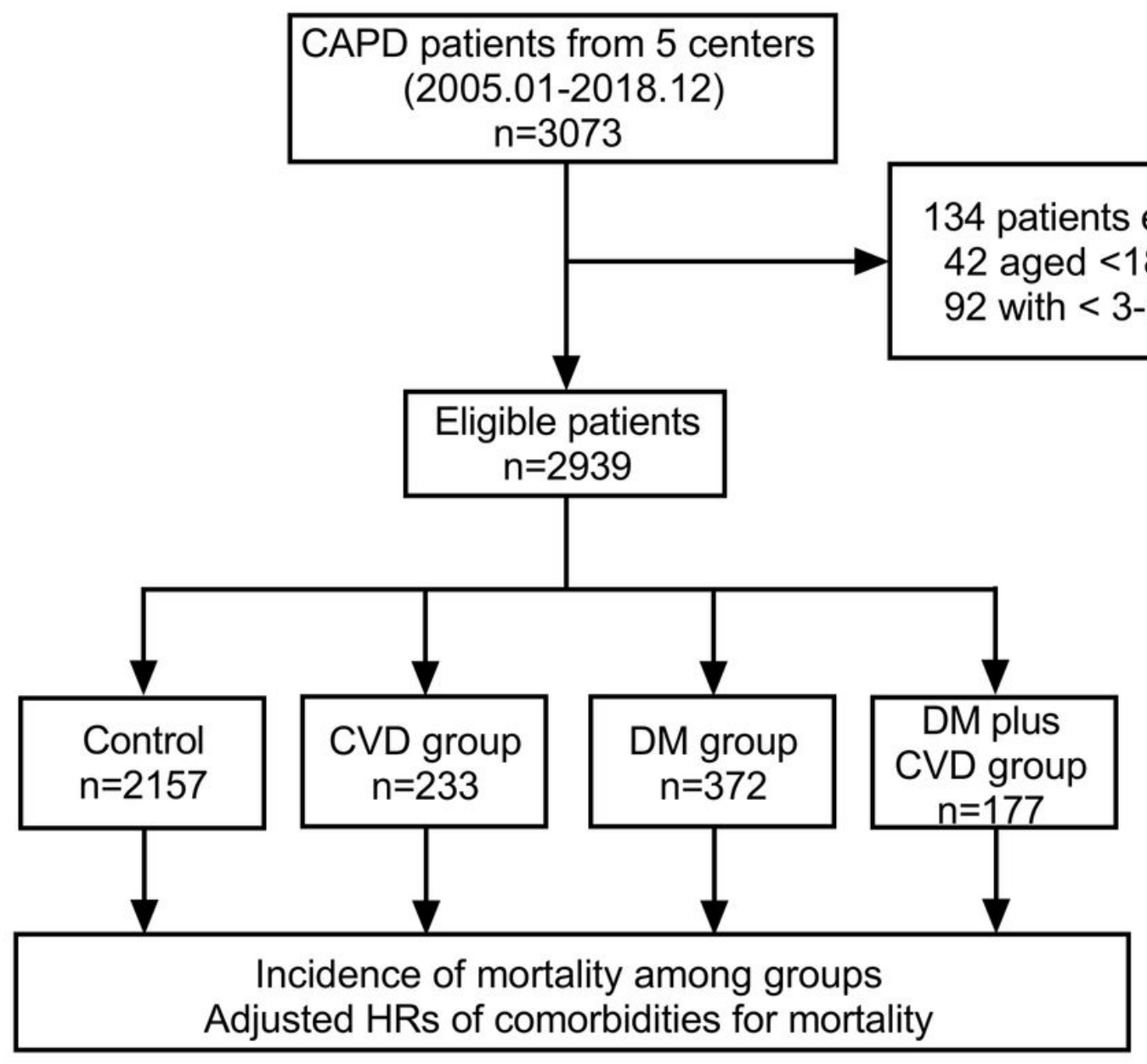

Figure 1

Flowchart. DM, diabetes mellitus; CVD, cardiovascular disease; CAPD, continuous ambulatory peritoneal dialysis.
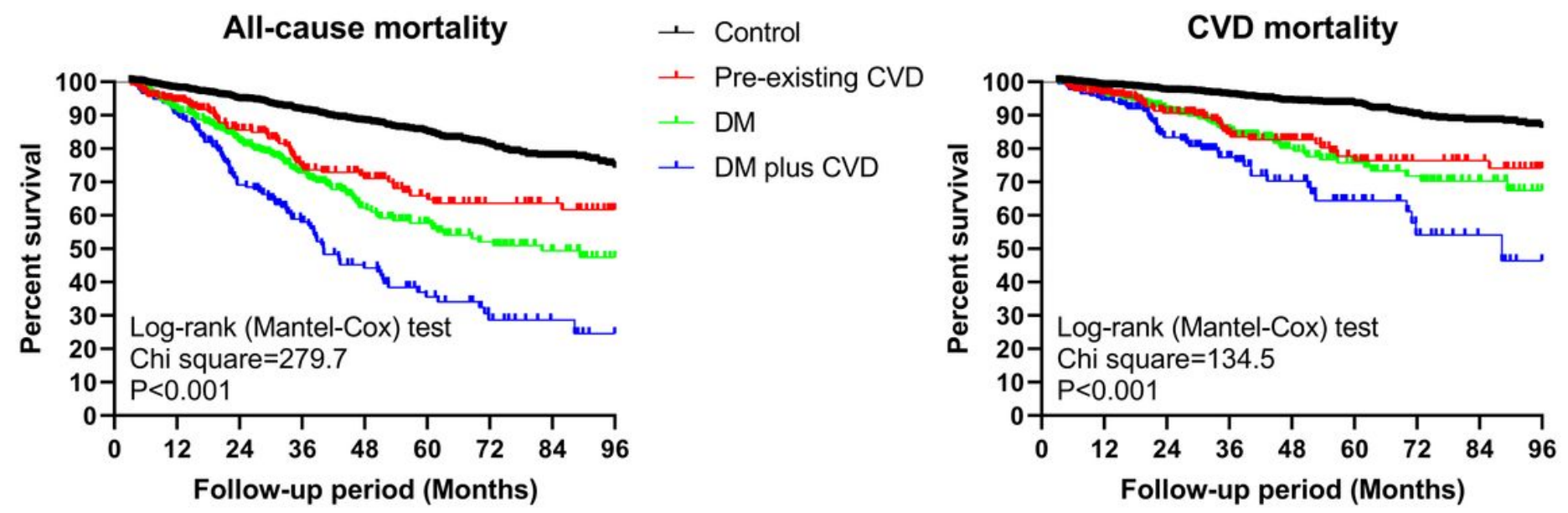

Figure 2 
Cumulative survival were lowest in those with co-existence of DM and pre-existing CVD. Control group: participants without DM and pre-existing CVD. DM, diabetes mellitus; CVD, cardiovascular disease.
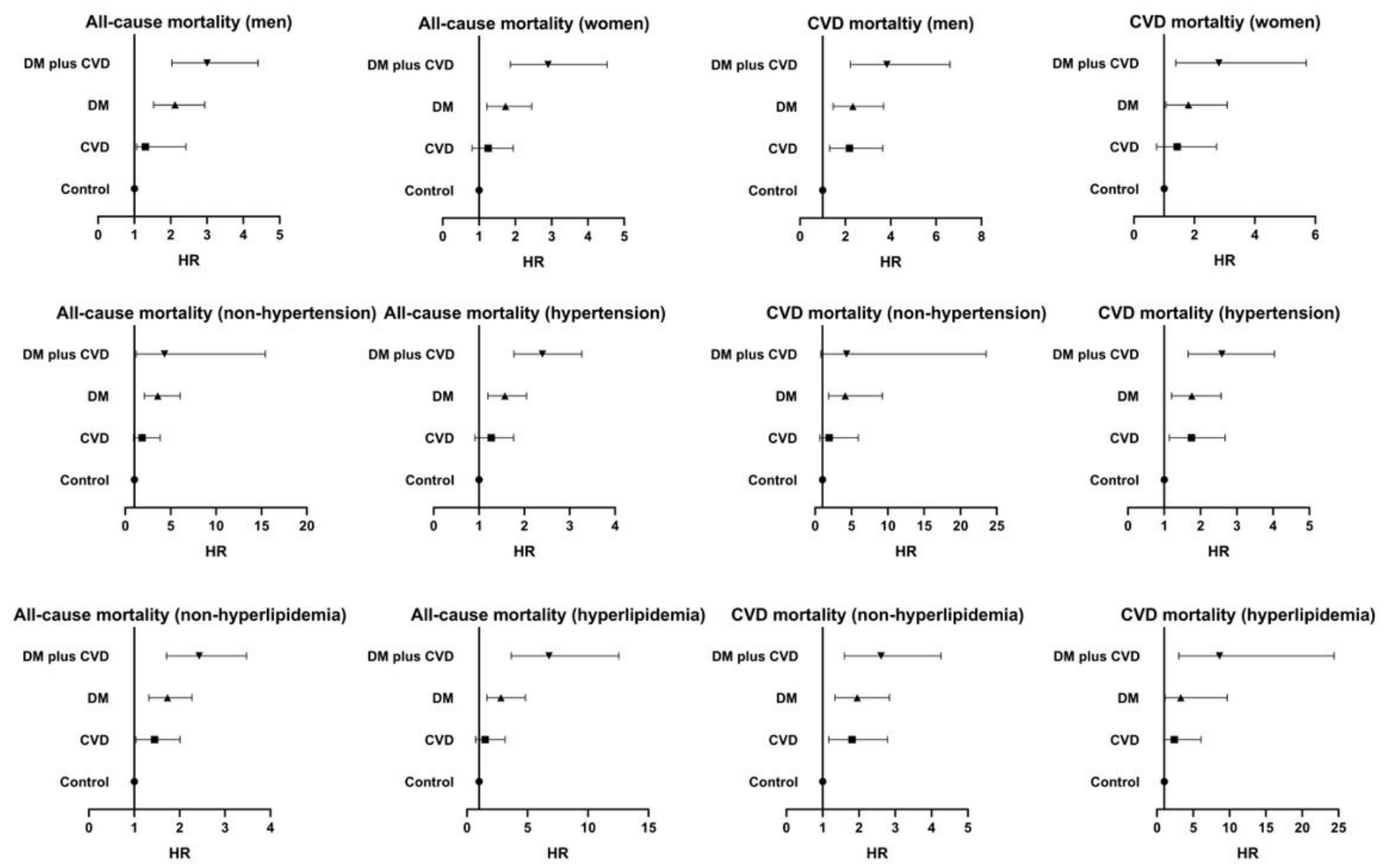

\section{Figure 3}

Adjusted HRs for all-cause and CVD mortality among subgroups. Model 1, unadjusted; model 2, model 1 plus age sex, body mass index, systolic BP, diastolic BP, current smoking, current alcohol consumption, 24hour urine volume, diabetes mellitus, and hyperlipidemia; model 3, model 2 plus medications; model 4 , model 3 plus hemoglobin, serum albumin, serum uric acid, eGFR, cholesterol, triglyceride, high density lipoprotein, low density lipoprotein, and hs-CRP. Control group: participants without DM and pre-existing CVD. DM, diabetes mellitus; CVD, cardiovascular disease; BP, blood pressure; eGFR, estimated glomerular filtration rate; hs-CRP, high-sensitivity $\mathrm{C}$-reactive protein; $\mathrm{HR}$, hazard ratio; $\mathrm{Cl}$, confidence interval. 